\title{
REDD+ as a tool for state territorialization: managing forests and people in Laos
}

\author{
Sabaheta Ramcilovic-Suominen ${ }^{1}$ \\ Natural Resources Institute Finland, Finland \\ University of Eastern Finland, Finland
}

\begin{abstract}
This article analyzes the Reduction of Emissions from Deforestation and Forest Degradation (REDD+) policy process, through the lens of state territorialization in the Lao People's Democratic Republic (Laos). It explores the motivations, mechanisms and strategies that drive REDD+ policy design and its implementation in the country. The provinces selected for REDD+ activities within the Emission Reduction (ER) Program, as well as the various REDD+ pilot projects are located in the north, where shifting cultivation is widespread, but where the potential for REDD+ to address deforestation and carbon sequestration is not optimal. The provinces with high carbon sequestration potential and high rates of deforestation are not part of the ER Program due to development investment projects and political sensitivity in those areas. REDD+ acts as a tool for state territorialization in a number of ways, including: (i) by targeting the areas where shifting cultivation is widely practiced, aiming to regulate village forest uses and users, (ii) by protecting state political, economic and development goals and strategies, (iii) by leaving the profitable large-scale drivers of deforestation unaddressed, including large-scale land investments, hydropower, infrastructure and mining development, and finally (iv) by providing additional motives, tools and discourses for state territorialization, including funding, technologies and the narratives that support it. I highlight, however, that REDD+ is not the sole reason for state territorial politics and practices. Rather, the instrument is layered over previous histories of colonial and postcolonial territorialization processes, continuing a similar logic, rhetoric and management practices. The REDD+ design and its technical orientation, however, appear to provide additional motives, as well as a new pool of resources, technical assistance and technologies that intensify the practice and politics of state territoriality in Laos.
\end{abstract}

Keywords: Laos, REDD+, state territorialization, forest politics, drivers of deforestation

\section{Résumé}

Cet article analyse le processus politique REDD + (réduction des émissions résultant de la déforestation et de la dégradation des forêts) à travers le prisme de la territorialisation de l'État en République démocratique populaire lao (Laos). Il explore les motivations, les mécanismes et les stratégies qui guident la conception de la politique REDD + et sa mise en œuvre dans le pays. Les provinces sélectionnées pour les activités REDD + dans le cadre du programme de réduction des émissions, ainsi que les divers projets pilotes REDD +, sont situés dans le nord, où la culture itinérante est répandue, mais où le potentiel de REDD + pour lutter contre la déforestation et la séquestration du carbone n'est pas optimal . Les provinces à fort potentiel de séquestration

\footnotetext{
${ }^{1}$ Dr. Sabaheta Ramcilovic-Suominen, Natural Resources Institute Finland and Department of Geographical and Historical Studies, University of Eastern Finland. Email: sabaheta.ramcilovik-suominen "at" luke.fi. The author gratefully acknowledges funding from the Academy of Finland (grant number 285984), and all respondents in Laos who took part in the study. The author thanks and appreciates the assistance, help and kindness she received from Paula J. Williams, Irmeli Mustalahti and Sebastian Koch during her stay and fieldwork in Laos and Keith Barney, Yayoi Fujita Lagerqvist and Juha Kotilainen for their comments on earlier drafts of this paper. Thankyou to three extensive referees and editors. Thanks also to research assistant Anolay Vongsouthi for his help with data collection and with Lao-English translations and to Nick Quist Nathaniels for help with the English. Finally, Noora Rämö's kind assistance in producing the map of Laos is thankfully acknowledged.
} 
de carbone et à taux de déforestation élevés ne font pas partie du programme de réduction des émissions, en raison de projets d'investissement dans le développement et de la sensibilité politique dans ces domaines. La REDD + agit comme un outil de territorialisation de l'État de plusieurs manières, notamment: (i) en ciblant les zones où la culture itinérante est largement pratiquée, dans le but de réglementer les utilisations et les utilisateurs de forêts locales, (ii) en protégeant les objectifs politiques, économiques et de développement et stratégies de l'État, en laissant de côté les facteurs de déforestation rentables à grande échelle, notamment les investissements fonciers à grande échelle, l'hydroélectricité, le développement des infrastructures et de l'exploitation minière, et enfin (iii) en fournissant des motivations, des outils et des discours supplémentaires en faveur de la territorialisation de l'État, notamment: financement, les technologies et les récits qui le soutiennent. Je souligne toutefois que la REDD + n'est pas la seule raison des politiques et des pratiques territoriales de l'État. Au contraire, l'instrument se superpose aux histoires antérieures de processus de territorialisation coloniale et postcoloniale, poursuivant ainsi une logique, une rhétorique et des pratiques de gestion similaires. La conception de la REDD + et son orientation technique semblent toutefois fournir des motifs supplémentaires, ainsi qu'un nouveau pool de ressources, une assistance technique et des technologies modernes qui intensifient la pratique et les politiques de la territorialité des État au Laos.

Mots-clés: Laos, REDD +, territorialisation de l'État, politique forestière, moteurs de la déforestation

\section{Resumen}

Este artículo analiza el proceso de política del mecanismo de Reducción de Emisiones por Deforestación y Degradación de Bosques (REDD+), a través de los lentes de la territorialización del estado en la República Democrática Popular Lao (Laos). El artículo explora las motivaciones, mecanismos y estrategias que impulsan el diseño de política e implementación de REDD+ en el país. Las provincias seleccionadas para las actividades de REDD+ dentro del programa de Reducción de Emisiones (RE), así como los diferentes proyectos piloto se encuentran ubicadas en el norte del país, región en donde se encuentran extendidas actividades de cultivos itinerantes, pero donde el potencial de REDD+ en deforestación y secuestro de carbono no es óptimo. Las provincias con alto potencial de secuestro de carbono y altas tasas de deforestación no son parte del programa de RE debido al desarrollo de proyectos de inversión y asuntos de sensibilidad política en dichas áreas. REDD+ actúa como herramienta para la territorialización del estado en múltiples maneras, incluyendo (i) apuntando a las áreas dónde los cultivos itinerantes son extensamente practicados, aspirando a regular tanto usos de los bosques aldeanos como de sus usuarios, (ii) protegiendo los objetivos y estrategias del estado en el de desarrollo político y económico, dejando sin atender a los grandes motores de la deforestación lucrativa, incluyendo desarrollos a gran escala de inversiones sobre la tierra, proyectos hidroeléctricos y de desarrollo de infraestructura y minería; y, finalmente (iii) en proveer motivos, herramientas y discursos adicionales para la territorialización estatal incluyendo financiamiento, tecnologías y narrativas para respaldarla. Sin embargo, en este artículo resalto que REDD+ no es la única razón para motivar las políticas y prácticas del estado territorial. Más bien, este instrumento se encuentra revestido de capas de historias previas de procesos coloniales y postcoloniales de territorialización, continuando una lógica similar y prácticas de manejo. El diseño de REDD+ y su orientación técnica, sin embargo, parecen proveer motivos adicionales, así como un nuevo conjunto de recursos, asistencia técnica y tecnologías modernas que intensifican las prácticas y políticas de la territorialización estatal en Laos.

Palabras clave: Laos, REDD+, territorialización estatal, política forestal, motores de deforestación

\section{Introduction}

Since its initial formulation as an efficient, effective and equitable way to reduce emissions from deforestation and forest degradation (Angelsen 2008; Angelsen et al. 2009; Stern 2007), REDD+ has been framed in various ways, including REDD+ as:

(i) an environmental governance and participatory forestry intervention (Corbera and Schroeder 2011; Mustalahti and Tassa 2012; Thompson et al. 2011),

(ii) a mechanism for payment for environmental services (Fletcher et al. 2016),

(iii) a tool for recentralization of forests (Phelps et al. 2010), 
(iv) a tool for carbon commodification (Mahanty et al. 2013; Mahanty et al. 2015), and

(v) as a conservation fad (Lund et al. 2017).

Phelps et al. (2010) have argued that monetizing of forestry through carbon payments under REDD+ offer further motivations for the state to (re)claim control over forests. However, as I will discuss in this article, the motivations for strengthening state control over forest resources in the case of Laos relate to protecting the state's political, economic and development goals and strategies, rather than obtaining REDD+ payments. Emerging scholarly research on forest politics in general and the REDD+ in Laos in particular, points to two prominent trends in REDD+ process and piloting activities in the country. First, the REDD+ pilot projects in Laos have targeted small-scale, proximate and localized drivers of forest degradation, such as shifting cultivation practiced by forest communities (Dwyer and Ingalls 2015; Dwyer et al. 2016). Second and related, large-scale drivers of deforestation, such as forest conversion through hydropower, infrastructural development and mining projects - even though initially identified as drivers to be tackled in the REDD+ (DoF 2010) - are being bypassed in the piloting activities (Cole et al. 2017).

In this article, I undertake further analysis with regards to motivations, politics and strategies of the central governmental agencies engaged in the REDD+ policy process, as well as the political economy shaping the ER Program. In doing so, I extend Dwyer and Ingalls' (2015) focus on the politics of REDD+ pilot projects, to the wider policy process, as it evolves under the Forest Carbon Partnership Facility (FCPF) and its Emission Reduction (ER) Program, and the emerging Forest Carbon Fund (FCF). The inquiry into state territoriality politics and how it unfolds under REDD+ is informed by the theory of state territorialization (Rasmussen and Lund 2018; Sack 1986; Vandergeest and Peluso 1995), and political forests (Peluso and Vandergeest 2001, 2011; Vandergeest and Peluso 2006). In addition the more recent studies and literature that relate to the politics of state territorialization are also reviewed. In the context of forest governance in Laos, where forest resources are used by multiple users for multiple uses, state territorial politics aims to restrain the smaller and informal uses and users for the benefit of the more profitable ones. The requirements of REDD+ for technical detail (Myers et al. 2018) and strict rule of law represent additional tools for the state to reach out and strengthen the control over more remote villages and forest lands, but also the dwellers and users of these lands and forests. Some of those rural dwellers are ethnic minorities, with traditional and informal practices and rules in place (Katz 2010; Lund 2011; Moore et al. 2013; UNDP 2011a,b). Land and forest use allocation and delineation are - among others - some of the oldest tools in the use for management, not only of natural resources, but also of local residents, and for production and reproduction of social and power relations (Fox 2002; Lestrelin et al. 2013; Peluso and Vandergeest 2001, 2011; Rasmussen and Lund 2018).

At the global policy level REDD+ was proposed as a climate change mitigation mechanism which creates financial value for the carbon stored in forests (Angelsen 2008; Angelsen et al. 2009). The mechanism has been developed by the Parties to the United Nations Framework Convention on Climate Change (UNFCCC) in a series of meetings - known as the Conference of Parties (COP) - since 2005 (Angelsen 2017; Brockhaus and Di Gregorio 2014). Laos was one of the first 14 countries to become a REDD+ country participant under the FCPF in July 2008, and its REDD Readiness Preparation Proposal (R-PP) grant was accepted in late 2010 (DoF 2010). The REDD+ activities of Laos are also funded by the Forest Investment Program (FIP), the UN-REDD Program and various other bilateral and multilateral donor initiatives (Koch 2017; Mustalahti et al. 2017; Vongvisouk et al. 2016). Due to ministerial and sectoral rearrangements in amongst others the forestry sector, it was not until 2014 that the first Readiness Grant of US\$3.6 million was signed. After several years of inactivity regarding REDD+ (Vongvisouk et al. 2016), in 2015 Laos submitted the Emission Reductions Program Idea Note (ER-PIN) to the FCPF Carbon Fund, which is a precondition to obtain access to potential performance-based payments for emission reductions (MAF 2018). After the development of the ER-PIN and acceptance into the Carbon Fund pipeline in March 2016, REDD+ gained new momentum in Laos (ERPD 2018; Koch 2017). With the signed Letter of Intent (LOI) in July 2016, the country had 18 months to elaborate a full Emission Reduction Program Document (ER-PD) and needed to show substantial progress in terms of REDD+ Readiness. Since then, the key REDD+ policy actors, i.e. the Ministry of Forest and Agriculture (MAF), and in particular the Department of Forestry (DoF), jointly with its international development partners facilitating REDD + in the country, focused on developing the institutional 
and policy framework and capacity building needed for the ER-PD. Institutional and policy adjustments require a substantial amount of time for consultations and sectoral coordination, but this was not available due to the WB FCPF deadline for developing the ER-PD. This resulted in frustration among actors from the private sector and civil society groups, who felt excluded from the process. These actors dismissed the process as "a game and gain for consultants" and a "process of expensive high-profile political meetings" (quotations from interviews with private sector and Lao civil society, respectively, held at the central level). The ER-PD was accepted into the FCPF Carbon Fund at the $18^{\text {th }}$ Carbon Fund Participants Meeting in June 2018. The ER-PD and the national REDD+ strategy propose reduction of GHG emissions from the forest sector in six selected provinces, all situated in the northern part of the country, namely Houaphan, Luang Prabang, Sayabouri, Luang Namtha, Bokeo and Oudomxay.

\section{State territorialization: theoretical perspective}

Vandergeest and Peluso (1995) argue that territorial strategies are increasingly used by modern states to control populations and to manage critical resources within the borders of the state. Their understanding of state territorialization is informed by Sack who defines territoriality as an "attempt by an individual or group to affect, influence, or control people, phenomena, and relationships by delimiting and asserting control over a geographic area" (1986: 19). Following Vandergeest and Peluso (1995), I highlight the inherent aspect of exclusion and inclusion of people within particular boundaries and the control of their actions within those boundaries.

State territorialization involves three main stages. The first stage involves boundary making. Land, forest and other resources are first demarcated and categorized in terms of use and ownership structures. Typically, all lands and associated resources that are not claimed by any other group are claimed by the central state, as sovereign state lands and property (To 2015; Vandergeest and Peluso 1995). These state lands are further classified as protected areas, reserves, or production forests for example. Demarcation and registration of land, land titles and maps are the necessary key tools of state territorialization used since the colonial era to the present day (Vandergeest 1996; Vandergeest and Peluso 1995). Rasmussen and Lund (2018) show how maps serve two purposes - as geographical representations and as political representations. This is especially relevant in the present day where modern mapping technologies are easily accessible; such technologies facilitate demarcation and registration of land, and thus create new territories and legal spaces and legitimize new entitlements and exclusions. The second stage is rule-making and establishment of territorial administration. In this stage, statutory legal and policy frameworks are established, new or updated laws are enacted, and state agencies for law enforcement are set up. This stage relates to the co-production of territory and state authority (Rasmussen and Lund 2018). In the context of state territorialization, the state attempts to reserve the task of managing access, claims and rights for itself, usually to the detriment of non-state or traditional authorities (e.g. indigenous and traditional authorities). The third stage of the territorialization process concerns law enforcement. To have a practical meaning and tangible impacts, the maps, laws and the rights and restrictions that they cause need to be taken from documentation to practice; i.e. they need to be implemented and enforced. State territorialization is motivated by a mixture of highly interlinked economic, political, social and cultural rationales (Peluso and Vandergeest 1995). First, the motivation to gain control over natural resources and profit financially from their commercial exploitation, while at the same time collecting taxes from the people living close to these resources. A second logic is to collect information and organize surveillance and control of the population to ensure social cohesion and order (Scott 1998).

While the stages of territorialization - boundary making, rule-making and rule enforcement - remain particularly relevant for this article, more recent studies provide further understanding of state territorialization politics in natural resource management. Vandergeest and Unno (2012) argue that the global environmental interventions, with a strong push and lead from donors, can be seen as "neo-colonial." Proposing the concept of 'extraterritoriality', they denote how global environmental interventions can reinforce 'western' domination and create 'eco empires' that have much in common with colonial extraterritorial empires. Like Vandergeest and Unno (2012), Dressler et al. (2015) highlighting the role of transnational actors in shaping forest 
governance in countries like Laos, argue that the introduction of REDD+ leads to extraterritorial governance. This literature has mainly focused on the role of external actors (international NGOs and donors) and the imposition and conditional nature of carbon governance interventions and REDD+. Rasmussen and Lund (2018) on the other hand, suggest that despite new institutions and policy instruments brought from outside, governance of resources are built on old social/political relations. To (2015) analyzed illegal logging and state territorialization in Vietnam from the state territorialization perspective, illuminating the collusion and corrupt activities of state actors, for example using a logging ban to facilitate illicit procurement of timber. Most recently, Suhardiman et al. (2019) examine the state territorial politics of land-use planning in Laos, highlighting how the land governance process is primarily driven by the development targets of sectoral ministries. They critique the dominant view that sees land-use planning as a tool contributing to stronger land governance.

The article adopts a broad political ecology framing and approach, emphasizing the relevance of the interplay of multiple actors at multiple scales over a period of time in shaping human-environment relations (Batterbury 2018; Bryant 1998, 2015; Robbins 2004). Specifically, it focuses on the question of how this interplay leads to production of territories, constructed with an aim to create rules of inclusion and exclusion to resources within certain spaces, or territories, and in this way controls not only resources, but also people (Bassett and Gautier 2014; Sack 1986). Concerning the evolving literature surrounding REDD+ as a transnational environmental governance instrument, the article illuminates how state agencies and international development partners, use the instrument to reinforce their political and economic aims, by among others framing REDD+ as an apolitical and bureaucratic tool at the policy design level, while using it to limit forest communities' practices on the ground. The article also highlights how REDD+ is placed within a single economic sector (forestry and agriculture), where the leading political actors close the policy space for other domestic actors, such as civil society. This in turn maintains the current power structure and relations in the country. The leading REDD+ policy actors, based under the Department of Forestry (DoF) and supported by development partners, follow existing political and economic development aims and forest management logics. These include land use planning and allocation, limiting of pioneering shifting cultivation, and stricter enforcement of state laws in village forestry lands and remote highlands (see Ramcilovic-Suominen and Nathan forthcoming, for details on REDD+ implementation at the subnational levels).

\section{Methods and analytical approach}

The article builds on semi-structured interviews with 33 REDD+ policy actors at the central level. The potential respondents were identified and selected in several ways. REDD+ and forestry-related documentation (example REDD+ workshops and national level REDD+ meetings) were reviewed to provide a list of prominent organizational and individual actors. Apart from two international NGOs and two domestic research and academic organizations, the identified actors were exclusively from the governmental agencies and international technical assistance and donor organizations. Further potential respondents were identified in informal discussions and preliminary interviews carried out with eight key informants representing academia, international CSOs, international technical assistance and donor organizations.

The key informant interviews were carried out during January and February 2017 when the REDD+ process was discussed in an unstructured manner, and where key milestones, challenges and actors involved in the process were identified. Finally, a list of local non-profit associations (NPAs) operating in the natural resources domain were obtained from the Lao CSO Directory, and a list of private sector companies was compiled based on project reports and preliminary interviews. Pooling these sources of information gave a final list of potential respondents, which was discussed with two key informants (both of whom worked on the REDD+ process) in order to make sure that the key actors has been included. The 33 semi-structured interviews with actors at central level were conducted between April and August 2017 (Table 1). The interview schedule was discussed on two occasions with one of the leading experts of the Forest Carbon Partnership Facility 
(FCPF) process in Laos and with representatives from Laos and international scholars in the field. The questions were aimed at addressing the current stage of and issues concerning REDD+ in the country.

Interviews were conducted in both Lao and English, and with one exception were all recorded. They took between 1 to 1.5 hour to complete. All were transcribed and when needed, translated to English. The interviews were analyzed in terms of: i) Perceptions about REDD+ and the geography of drivers of deforestation, REDD+ pilot projects and FCPF activities; ii) actors, their motivation, roles and participation in REDD+. The first step of the analysis was coding of text by defining broad categories of relevant themes. Next, these themes were further elaborated into subthemes for more detailed analysis. This resulted in emergence of clear patterns in opinions and positions on specific critical issues and formed the basis for deriving the final results outlined in this article.

\begin{tabular}{|l|c|l|}
\hline Organisation category & $\begin{array}{l}\text { Number of } \\
\text { respondents }\end{array}$ & Description \\
\hline $\begin{array}{l}\text { State organisations and Lao } \\
\text { technical to } \\
\text { government }\end{array}$ & 6 & $\begin{array}{l}\text { Includes Government of Laos (GoL) staff and individual } \\
\text { Lao individuals who provide technical assistance or } \\
\text { consulting services to the GoL in implementing REDD+. }\end{array}$ \\
\hline $\begin{array}{l}\text { International development } \\
\text { partners and technical } \\
\text { assistance }\end{array}$ & 8 & $\begin{array}{l}\text { Includes international development partner organizations } \\
\text { and individuals who provide technical assistance or } \\
\text { consulting services to the GoL. }\end{array}$ \\
\hline Foreign private sector & 3 & Foreign forest companies. \\
\hline Lao private sector & 4 & Lao domestic forest companies. \\
\hline $\begin{array}{l}\text { International civil society } \\
\text { organisation (CSOs) }\end{array}$ & 6 & Domestic CSOs based in Laos. \\
\hline $\begin{array}{l}\text { Lao CSO (civil society } \\
\text { organisation) }\end{array}$ & 4 & Lao domestic research and academy organisation staff. \\
\hline Academia and research & & \\
\hline
\end{tabular}

Table 1: Responding organisations.

\section{Reinventing REDD+ in Laos: From carbon funding to funding 'forestry as usual'?}

Despite the fact that REDD+ instrument deals with drivers of deforestation and forest degradation beyond forestry sectors, at the central level the instrument is confined within the Department of Forestry (DoF) at the Ministry of Agriculture and Forestry (MAF). At the time of this research, most of the 'REDD+ experts' and policy makers with decision-making power at national and subnational levels were based under the REDD+ Offices and various REDD+ Technical Working Groups (TWGs). The sectors' involvement and their roles is described in more detail in Ramcilovic-Suominen and Nathan (forthcoming). In this article, when referring to 'the state' or 'the government', I refer to the handful of these state agencies involved in REDD+ activities.

These governmental agencies implement REDD+ with a strong support from the existing development partners, including the following as the most important ones in REDD+ implementation: World Bank (WB), Japan International Cooperation Agency (JICA), German Development Agency (GIZ), and Finnish Ministry of Foreign Affairs, whose role and support were significantly reduced in 2017. In addition, Food and Agricultural Organization (FAO) and Asian Development Bank (ADB) provide support, funding and expertise in implementing REDD+. These donor and development partners play a crucial role in supporting forest 
governance processes, including REDD+, by providing financial and technical assistance to governmental agencies, at both policy design and piloting level. ${ }^{2}$

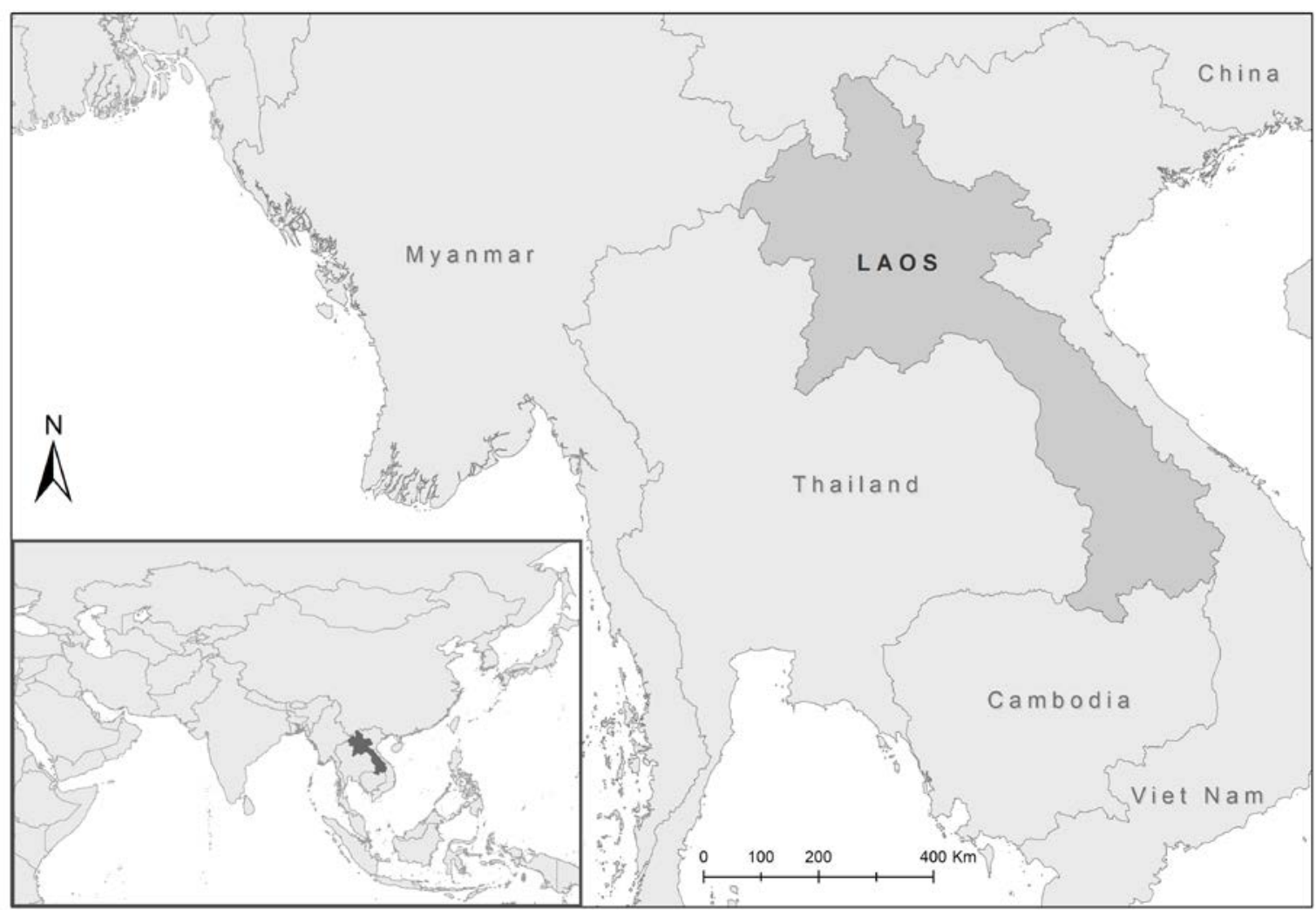

Figure 1: Map of Laos. Drawn by Noora Rämö.

Shifting motivations within REDD+: from lucrative REDD+ payments to donor funding to support 'forestry as usual'?

At the central level, all actors, including the government-based REDD+ actors, civil society and development partners told how the early motivations and expectations for engaging with REDD+ in Laos were predominantly related to the monetary benefits. A decade later, financial motivations for REDD+ performancebased payments have vanished, leaving REDD+ donor funding and the prospects for generous investments under the Forest Carbon Fund (FCF) to be the main financial motivation for engaging in REDD+. The dashed expectations for REDD+ funding are well captured by the following explanation, derived from interviews with respondents from development partner organizations and the governmental agencies at the central level. Five respondents using the same figures explained that expenses for implementing REDD+ in the six ER provinces are estimated at a minimum of US\$100 million over a period of 6-7 years. Funding estimates for selling carbon credits from these six provinces for a six-year time period are cumulatively about US\$30 million, as a onetime payment. When the latter figure is divided per province and district, village and household, this becomes a negligible amount of a couple of US dollars per household per year. Referring further to the deforestation that has been avoided as a result of the decrease of timber export to Vietnam, from 1 million $\mathrm{m}^{3}$ to $250,000 \mathrm{~m}^{3}$

${ }^{2}$ See Broegaard et al. (2017); Cole et al. (2017) and Lestrelin et al. (2013) on the roles of the development partners in natural resource policy and governance instruments. 
in in the aftermath of Prime Minister's Order (PMO 15) in 2015-2016 (To et al. 2017), a representative of a development partner organization stated that based on their calculations:

All the wood that was not exported (over the) last 2 years to Vietnam, due to PMO 15, all that reduction in $\mathrm{CO} 2$ emissions and the Carbon sequestrated - and it was a significant reduction - if sold at a current price of 5 US\$ per ton of CO2eq, it means 20 million. 20 million US\$ that Laos would get from that reduction, and it's a one-time payment as per the FCPF scheme. So REDD+ offers nothing compared to selling timber, which for that amount would roughly be about 1 billion US\$.

The ER-PD published a year after the interviews took place, clarifies the alleged high expenses for REDD+ implementation, which are not matched by the expected revenues from selling carbon sequestrated in those provinces. The ER-PD (2018: 90) reads that: "Based on the aggregated six PRAP [Provincial REDD+ Action Plans] costs and the enabling environment interventions for the central Government level, the total ER Program cost is estimated at US\$136.5 million for the period of the ER Program implementation (i.e. 20192025)." While the former figure refers to REDD+ payments for reduced emissions and the later to the investment for implementation of REDD+ in the six ER Program provinces, these figures are nonetheless indicative of the low-income generation prospects within REDD+. This in turn defines what drivers of deforestation are likely to be addressed within the REDD+ process.

If performance-based payments under REDD+ does not provide the motivation for engaging with REDD+, what does? As far as the financial motivations are concerned, the main incentives for the central state actors, as well as the international development partners, related to the availability of the REDD+ donor funding for the REDD Readiness phase and the expected investments under the FCPF proposal. Using "REDD+" as a catchword and "putting the REDD+ hat on" as a useful technique for acquiring funding to carry on with largely similar and in some cases ongoing project activities, was mentioned by many development partners and respondents from governmental sector. Thus, the project activities undertaken within REDD+ program are likely to resemble the existing, well-established policy measures and project activities.

For the vast majority of Lao domestic actors, including governmental agencies, the Lao NPAs and academia, the key objectives and motivations for the Lao government to engage in REDD+ relates to MAF's aim to support the forest sector and forestry strategy, which aims to increase the forest cover to $70 \%$ by 2020 , which is in turn linked to economic development. An academia respondent stated that "Laos is currently developing its economy. It is based on the electricity from hydropower. If you based your economy on the electric sector, you need to manage forests well. Forest preserve watersheds. So, forests are necessary for our key economic driver that is hydropower." The other motivation respondents claimed is the MAF's main aim in REDD+ is to bring forest communities on board to protect forests and to limit their shifting cultivation farming practices. ${ }^{3}$ Respondents across different sectors argued that the main motivation for the central government to work with REDD+, concerns management of village forest land, village forest demarcation, mapping and landuse allocation. As the respondent from governmental sector explains: "For us REDD+ is more about nonmonetary benefits (that would result) from implementation of the project. For example if we can create our village forest mapping, participatory land use planning and mapping, and if we can monitor forest communities and their work." Mapping and demarcation, as a way of "knowing the land, knowing the people" was aired as one of the key aspects in REDD+, by the respondents across the administrative levels. As the Lao technical advisor to the government stated: "Many people want to develop the land demarcation, reduce shifting cultivation. Because, if this is clear, we know where the forest is more abundant, where the forest is less

\footnotetext{
${ }^{3}$ The farming practice of shifting cultivation includes burning vegetation - forest included - to farm crops for a few seasons and then shifting to another forest patch, but returning again to the old patch once the vegetation has recovered and soil fertility has been restored (Cramb et al. 2009; Fox et al. 2009). While the practice represents the main livelihood activity and central part of culture in the mountainous northern part of Laos (Cramb et al. 2009; Dressler et al. 2016), it is also used for commercial cultivation of maize and other crops, often for foreign commodity production and investment.
} 
abundant, how many villages are located there, and how we categorize the different types of forest and villages (...). This is a more important aspect (than REDD+ payments)."

\section{Political ecology of drivers of deforestation in the selection of ER Program pilot provinces}

Following Thomas et al. (2010), the main drivers of deforestation in Laos include large-scale land conversions for agribusinesses, industrial tree plantations, mining and hydropower projects, while the main drivers of forest degradation include pioneering shifting cultivation and formal and informal logging. Other academic and policy literature is in agreement that both large and small-scale operations are significant drivers of deforestation and forest degradation (FCPF 2015; Ingalls and Dwyer 2016; Koch 2017; Lestrelin et al. 2013; PRAP 2017). But, the majority of the respondents from the government and international development partners maintain that the most important driver in Laos is the practice of shifting cultivation. As a respondent from a development partner states:

I am not clear on the situation at the national level. I only know about the data that [name of a person] has provided, on the PFAs [stands for Production Forest Areas]. And, if you have talked to [name of the person] already, [they] may have told you that the main drivers are small-scale agricultural expansion and shifting cultivation. I mean, how large were these hydropower. I mean, you cannot really see them on the map. Ok there is a reservoir here and there, sure it is something, but when you look at the area of, like, shifting cultivation right, then there is not much area of deforestation coming from hydropower.

The two key reasons for the predominant focus on the local forest and land uses and the lack of attention to deforestation resulting from large-scale land intensification and forest conversions to various industrial land and forest uses, include: 1) the political economy and power structure that protects large-scale business and targets small-scale informal forest uses, and 2) the long standing policy objective of tackling shifting cultivation in the northern part of the country. The results uniformly suggest that the private sector actors have already ensured their legal hold on the land and resources, and that there is no ground for negotiating any competing schemes, such as REDD+, in those areas. Respondents pointed out that certain land uses, such as mining, hydropower and agricultural concessions, are already registered and that "there cannot be an overlap between those and REDD+ activities", as the respondent from the governmental sector stated. In addition, the realization of thin financial benefits from REDD+ schemes, as explained in the previous section, were brought up. A respondent from government argued that:

...the small-scale drivers become large-scale, meaning that the population in rural areas, as we know, mainly depend on natural resources. Therefore, if development projects, national and international, focus on the small-scale drivers, raising awareness of these villagers, to make sure that they understand the benefits of forest [...]. If individuals that live close to forest, if they understand that, they will automatically preserve the forest.

These arguments portray rather well the philosophy and de facto practice of development politics in Laos. Highlighting further the political culture and power structure, a number of respondents, including those from the governmental agencies, argued that the government backs large-scale businesses and that the development partners cannot go against this authority. A Lao technical adviser to the DoF expressed this view:

For the external actors, like international TA [technical assistance], it is difficult to address largescale drivers, or the big projects that impact the forest, as they are driven by the national policy interests and because the GoL (Government of Laos) gives the authorization. So, for the 
development organizations, it would be better, easier to address the small-scale drivers that do not interfere with politics, or with the objective of the GoL. I think it is like that.

As stated by another governmental representative: "Targeting the easiest and the least politically sensitive issues in REDD+ is in everyone's interest."

Looking further into the politics of state territorialization, elements of political ecology in terms of REDD+ localities come to light. With the exception of two WWF REDD+ pilot projects and a public-private partnership project operating in the south (see Dwyer and Ingalls 2015), the majority of REDD+ pilot projects are in the northern Laos. Similarly, the recently submitted ER-PD includes the six northern provinces as ER Program pilot provinces. However these provinces appear poorly chosen, when emission reductions are considered, since deforestation rates and carbon sequestration potentials are higher elsewhere. The majority of respondents highlighted there is less forest and land investment compared to central and southern parts of Laos and that there is a general mismatch between deforestation rates and the location of ER pilot provinces, just as there is between deforestation rates and REDD+ pilot projects (see Dwyer and Ingalls 2015; Pasgaard and Mertz 2016). This is well captured by a respondent from a development partner organization, when they described negotiations with the DoF concerning the locations of the ER Program provinces, and locations of their own REDD+ pilot project:

When in the beginning we discussed about the early idea for the Carbon Fund, that's what I told you; we proposed based on the REDD principles - where there are the highest carbon stocks, and where deforestation is at the highest. That is different provinces then the six provinces they selected for the ER Program. Bolikhamxay, Xaysomboon, Vientiane Province, they are some with the highest carbon stocks, and also high deforestation. But this proposal was not accepted. There is a lot of Chinese investment going on in Vientiane Province and Bolikhamxay.

The same respondent elaborating further the key criteria posed by the DoF for selecting REDD+ pilot sites, argue that the DoF focused on the areas with ethnic minorities:

On the other hand, they [referring to DoF] were saying that in Laos, REDD should focus on working on the 'plus', and then we should focus in the northern provinces, where the most ethnic minorities, ethnic groups live and where the poorest places of the country are, poorest districts and poorest villages with ethnic groups, Hmong, and others.

As suggested by the interview quote, poverty in the northern Laos is strongly associated with ethnicity, agricultural practices, but also culture and education levels. Many respondents from the governmental agencies and from the Lao NPAs thought that not only were the people in the northern Laos poorer and more likely to practice shifting cultivation, they were also less 'educated and emancipated' and need to be exposed to both state laws and policies as well as to economic opportunities.

\section{State territoriality and political forests}

\section{The Lao State in the making and the management of people and natural resources: from past to present}

After the fall of the Lam Xang kingdom at the end of the 17th century, the area of the present day Laos was split in three kingdoms - the Kingdoms of Luang Prabang in present day northern Laos, Vientiane in central Laos, and Champassak in the south of the country (Evans 2002; Stuart-Fox 1997, 1983). The kingdoms' tenuous independence, threatened by neighboring kingdoms, finally collapsed when mainland Southeast Asia fell under the French colonial empire at the end of 19th century. The French ruled Laos for half a century (Stuart-Fox 1997). They had a profound impact on the country, preventing its extinction at the hands of more powerful Thailand and Vietnam, while also "permanently reducing it to a dependent and minor power" in the 
region (Evans 2002; Stuart-Fox 1983: 435). During French rule, the traditional authority and traditional cultures were significantly weakened (Stuart-Fox 1983). As French colonial rule itself weakened, the Royal Lao Government was established within the French Union in the last years of French colonialism, in 1947. Shortly after, in 1954, French colonialism in Indochina and Laos collapsed.

As typical for the strategies of colonial power in the region (Alden Wily 2012; Kelly and Peluso 2015; Peluso 2005; Peluso and Vandergeest 2011), the French established governance models and introduced concepts foreign to the country. ${ }^{4}$ After French colonial rule collapsed in 1954, the country saw a rise in nationalism, and revolutionary uprising by minorities of which most prominent was that of the Hmong minority (Evans 2002; Stuart-Fox 1997, 1983). Finally, a civil war between what was left of the Royal Lao Government and the emerging communist establishment began in the early 1960s and lasted until 1975. At this point, the Lao People's Revolutionary Party (LPRP), which was supported by Vietnam, won the battle over the royal establishment and their allies - the United States (Evans 2002; Stuart-Fox 1997, 1983). The war left the country devastated and on the verge of social and economic collapse, which resulted in starvation and devastation of the freshly established independent socialist Lao Peoples' Democratic Republic. Heavy bombing by the U.S. induced massive migrations of rural populations from the eastern to the western part of the country, as they sought to reach refugee camps in Thailand. Among them many Hmong, who under Colonel Vang Pao were on the side of the U.S., also attempted to flee the country and avoid prosecution and 're-education camps', or prison camps (Evans 2002). These camps saw some 10,000 to 15,000 people imprisoned for as long as 13-15 years (Kingsbury 2016: 43; Evans 2002: 181).

These movements and hardship are of relevance to this study, since the people fleeing the war and the war 'traitors' fleeing persecution after the war settled in temporary 'makeshift' villages, in the highlands and mountains, and cleared the forests for shifting cultivation and produced opium. Many of these 'war defectors', including Hmong, still reside in the mountainous parts of Laos. At the time when the French arrived, Laos represented a rich mosaic of ethnic minorities due to previous migration movements, and ethnic Lao made up just about 50\% of the total population (Evans 2002). Laos has since been ethnically heterogeneous and divided, with certain minorities integrated less than others. The Hmong ethnic minority is an example of a minority that has preserved its cultural heritage and which also remains at odds with the Lao government (Baird 2010, 2015). Ethnic integration in Laos is a modern construct, enshrined in the Lao Constitution of 1991.

After the war, the new regime commenced land and agricultural reforms in order to promote agricultural collectivization - an effort which never succeeded in Laos (Ducourtieux et al. 2005; Evans 2002). Another experiment of the new Lao government, which did succeed and had a profound impact on the country's economy and environment was the establishment of state-owned enterprises (SOEs) (Evans 2002; Stuart-Fox 2006). SOEs generated the much-needed revenue for the nascent nation, but due to mismanagement and corruption resulted in massive forest degradation and environmental devastation (Evans 2002; Singh 2012; Stuart-Fox 2005, 2006). Finally, a policy that has been repeated and continued since 1975 is resettlement, moving people from highlands to lowlands, or mobilizing 'upland people' to more accessible and close-tomarket areas, in the quest for 'civilization' and development (Baird 2010, 2015). Various narratives including ethnic integration, building of national unity and emancipation of highlanders, as well as limiting shifting cultivation and opium production, are named as reasons for the persistent policy (Baird and Shoemaker 2007; Lestrelin 2010; Singh 2012).

The failure of agricultural collectivization, the environmental and forest degradation caused by the SOEs, and the economic downturn following withdrawal of foreign support by the war allies after the war (Evans 2002; Stuart-Fox 1997; Phraxayavong 2009) led Laos to open its doors to the open market economy

\footnotetext{
${ }^{4}$ Including: (i) the concept of the nation state; (ii) the 'civilization' of the Lao population, known as "turning peasant into a Frenchman" (Evans 2002: 42); (iii) introduction of scientific forestry and mapping and registration of lands and people. Most of these activities, concepts and models would later be adopted by the independent Lao state, continuing the colonizing legacy.
} 
and engage in reforms in resource management. ${ }^{5}$ The shift to the open market economy also meant better political relations with the international donor and development community, which soon became important tool for the Lao State (Lestrelin et al. 2012; Stuart-Fox 2005). The most prominent of these donor and development agencies are the United Nations (UN), including especially its FAO, as well as the World Bank, the Asian Development Bank (ADB), the Swedish International Development Agency (SIDA) and bilateral development partners including Finland, Japan and Germany (Lestrelin et al. 2012; Ramcilovic-Suominen et al. 2019; Stuart-Fox 2005). Each of these brought their shared notions and discourse of sustainability, environmental conservation and protection, as well as the notions of decentralization of power and quest for popular democracy. Laos soon adopted this trend of internationalization, mainly as a strategy to derive a valuable influx of donor funding, loans and revenues (Stuart-Fox 2005), while keeping a strong regulated approach to and control of market and forest resources (Ramcilovic-Suominen et al. 2019; Singh 2012). This in turn led to the start of an endless process of policy and institutional building and reforms to adopt to the changing demands of international forest governance instruments.

The global discourses of sustainability, establishment of natural protection areas, biodiversity protection and lately climate change, promoted by international actors has been appealing to the GoL, among others, as a legitimizing tool for eradicating shifting cultivation and likely as a mean to control the ethnic minorities practicing it (McElwee 2016). Shifting cultivation is widespread in the mountainous parts of the north of the country and is practiced by ethnic minorities of whom some still remain rather independent and separate from the state and the rule of state law, following their own traditions, customary rules, and livelihood in a broader sense (Moore et al. 2013; Singh 2012; UNDP 2011a,b). With the help of international development partners, the Tropical Forest Action Plan was developed in 1989, which called for forest conservation and tree plantations over an area equivalent to $70 \%$ of the country (Lesterelin et al. 2012). Among others, the Plan recommended resettlement of two-thirds of the population engaged in shifting cultivation (estimated at around 170,000 households) (Evrard and Goudineau 2004). The international development partners therefore brought discourses as tools for legitimization, but also introduced policy change and brought in tangible tools and technologies needed to implement interventions in natural resource governance.

\section{Phases of state territorialization in Laos}

Based on the overview of Lao history and management of resources and the REDD+ policy process presented above, I next outline the identified phases of state territorialization in Laos. The first phase being state territorialization under French colonial rule, undertaken in the name of consolidating French colonial power in the region (1893-1953). In this phase models of governing the land, forest and people were introduced, which had continued in some form until present day, being adopted as a model of governing and development by the independent postcolonial nation state. The most prominent examples include forest and land inventories, categorization and mapping of land, forest and other resources; but also registries of people and a quest for modernization of peasants and highlanders (Alden Wily 2012; Peluso 2005; Peluso and Vandergeest 2011; Scott 1998). As discussed in Evans (2002), but also in Singh (2012), modernization of the domestic backward culture, their agricultural practices and way of life was the key goal of the French La mission civilatrice (civilizing mission). The second phase of state territorialization was under the newly established socialist Lao government, in the name of socialism and centrally planned economy (1975-1990), and is categorized by extractive activities, especially logging and export of round wood to neighboring countries. The trade was largely used as a way to repay the wartime debt. The timber was - and still is today - sold at lower than market prices in recognition of political alliances and as thanks to war allies (Vietnam) for their support of the joint communist cause in the war (Evans 2002; Singh 2012). This period is also characterized by experiments to

\footnotetext{
${ }^{5}$ This period of environmental awareness-raising, which was marked by the first national conference on forestry in 1989 to address the problem of deforestation, is referred to as the "beginning of a new era" (Fujita 2006), a "new development phase" (Lestrelin et al. 2012). In reality, however, this new era meant a shift from state or national extraction to multinational extraction of forest resources (Barney 2008, 2009; Kenney-Lazar 2011, 2017). Laos embarked on intensive resource-driven development, characterized by a resource and land rush by international multinational companies, for rubber and agricultural concessions, infrastructure development, hydropower and mining, rendering Laos as the new natural resource frontier (Barney 2009; Kenney-Lazar 2011).
} 
establish socialist models of production, such as agricultural collectivization - which did not succeed in the war-torn country. Finally and importantly, the policy of resettlement of 'highland people' engaged in shifting cultivation and opium production was started at that time, as a part of larger state building, which remains relevant to the present day (Baird 2010, 2015; Kenney-Lazar 2013). The third phase is state territorialization by the Lao government and international development partners, undertaken in the name of sustainable development and conservation (late 1980s to present). This phase emerges as a backlash to corruption and extraction of forest resources over the previous 15 years. The aim in this phase is to develop forest policy and an institutional framework based on the notion of sustainability, and to establish the rule of law and scientific forestry tools and technologies (e.g. forest and land inventories, forest plans and maps). The phase is characterized by adoption of the new market economy, institutional and capacity building, establishment of forest and land laws, logging bans and categorization of forest land into production, protection (i.e. national protection areas) and conservation forests. These legal and governance reforms were needed to support the new market-oriented economic and governance approach and its neoliberal agenda. The early 2000s saw an effort to establish longer-term policies and laws as a response to 'short-termism' and responsive policymaking in Laos (Ramcilovic-Suominen et al. 2019; Smith 2016). A forestry strategy and a national growth and poverty eradication strategy were developed in 2005 and 2004, respectively. These strategies were enacted in order to direct institutional and policy frameworks for sustainable forest management. Parallel with this ongoing phase is the fourth phase of state territorialization by the Lao Government, international development partners and multinational corporations (2000-present), undertaken in the name of 'turning land into capital'. The phase refers to the foreign private sector rushing to secure their hold over land and resources, reducing further the land and resource endowments for the local population. In this phase, there is a tendency to conserve forest resources that are used for subsistence, while resource extraction in the frame of 'turning lands into capital' (Baird 2011; Dwyer 2007) is allowed. Since early 2002 large-scale land concessions for rubber and agricultural plantations, large-scale mining, infrastructural development and hydropower development projects have boomed (Barney 2009; Dwyer 2014; Kenney-Lazar 2011). Key strategies used in connection with land investments have included (i) allocation of insufficient land for agriculture and shifting cultivation (Lestrelin 2010) and (ii) mapping swidden land for shifting cultivation as 'empty' or 'degraded' and allocating it for land investments; this has resulted in severe impacts on local communities (Baird 2011; Barney 2008). Across the four phases of state territorialization, we see a similar trend of management of people and resources, via exclusion, 'fortress conservation', and forest and land demarcation and allocations schemes.

\section{State territoriality as it unfolds within the REDD+ policy process in the country}

While state territorialization is exemplified through the domestic REDD+ process in this article, the same is indirectly enabled by policy design at the global policy levels. For instance, the REDD+ monitoring, reporting and verification (MRV) of carbon, as well as the REDD+ benefit sharing schemes as framed at the global level, require clear land and forest use categories and clear ownership. Establishing clear land and forest use categories and tenure arrangements at the local level may result in dispossession of local people in the interests of political and economic elites, as appears to be the case in Laos when looking at the drivers of deforestation addressed in REDD+. Further research at the village level is needed to shed light on detailed implications REDD+ piloting activities on the local communities' access and rights to forests in Laos.

The tangible ways in which state territorialization takes place within REDD+ in Laos include:

(i) targeting of village forestry activities and attempting at better management of village forests,

(ii) protecting the economic and political interests of the elite, by keeping the profitable activities that also lead to deforestation away from REDD+ (i.e. large-scale land investments, hydropower, infrastructure and mining development), and

(iii) by providing motives and tools for state territorialization, including funding, technologies and the narratives that support it. 
These are evident mainly in the technical character of the instrument, such as MRV and carbon accounting, which require clear forest categories, ownership structures, resource inventory and mapping. While these technologies and knowledge are necessary for REDD+ implementation, they also represent potential and common tools used in state territorialization efforts in Southeast Asia and other post-colonial societies (Alden Wily 2012; Kelly and Peluso 2015; Lund and Rachman 2018; Rasmussen and Lund 2018). State territorialization described in this article occurs at the policy level, as REDD+ is embedded through the broader landscape of national territorialization processes, interacting with other institutions and policies, and thus it jointly contributes to shaping the landscape of resource control, conservation, extraction and exclusion.

Some of the aspects promoted and strengthened in REDD+ implementation, such as clarification of forest and land categories, tenure and rights, as well as strengthening of law enforcement can be encouraging and welcoming developments. Yet, the outcome of such processes often lead to unintended outcomes, and will depend on power relations, but also the extent to which social justice aspects are taken into account in their implementation. Further, the possibility that the selection of ER pilot provinces may serve other purposes, such as poverty alleviation, is not excluded. Similarly, it is very possible that the presence of donors and development partners in the north may have influenced the selection of ER Program pilot provinces. And, finally, REDD+ as currently implemented in Laos, could contribute to strengthening of the forestry sector through (for instance) capacity-building and support of forestry administration. But, in this article, by situating the study in the specific Lao historical and political context, and through a critical literature review of forest governance and state territorialization, I aimed to uncover other hidden, and in some cases not so hidden political and economic motivations influencing REDD+ process in the country.

Scholars have observed similar trends in state territorial politics beyond REDD+ and beyond Laos. Suhardiman and Giordano (2014) for instance show how, in the case of hydropower development in Laos, the central state - despite and also because of legal pluralism - has been able to use contradictory mandates to further its goals and agendas at the cost of competing institutional and legal orders. Lavers (2012) and Lavers and Boamah (2016), studying power relations between, and motivations of, different types of authorities in Ethiopia and Ghana show how land use policy changes in these countries have been used to promote international agricultural investments and have benefited not only foreign investors, but also the domestic power structures and authorities. Specifically, as observed in the case of the Lao REDD+, Lavers (2012) discusses how government interests and goals regarding international land and agricultural investments go beyond control over resources to controlling and reaching areas populated by ethnic minorities in the country. This article suggests that while REDD+ offers an important venue for transnational actors to shape the domestic forest governance in Laos, as pointed out by Dressler et al. (2015), the space for those actors to influence the larger picture of forest governance is rather limited. This is because the instrument is increasingly embedded in existing social and political relations, continuing the existing logics, narratives and practices that solidify the status quo, rather than enabling significant change. This observation is in in accordance with Rasmussen and Lund (2018) who suggest that despite new rules and institutions, governance of resources mainly remain within the existing social and political establishments, also highlighted by Milne et al. (2018) who analyze REDD+ processes in Southeast Asia.

\section{Conclusions}

In this article I have analyzed REDD+ as an instrument facilitating the state territorialization project in Laos. I have assessed the motivations of the GoL at the central level to engage in REDD+, and the politics behind addressing specific drivers of deforestation and forest degradation, as well as the selection of geographical areas where to implement the REDD+ ER Program. The study shows how by depoliticizing (i.e. avoiding politically contentious issues, such as forest tenure and rights to forests) and 'de-economizing' forestry (i.e. avoiding economically profitable activities thriving on forest destruction), the central governmental agency leading the REDD+ process use the instrument to strengthen central state control over local forest resources, users and their practices, while enabling continued large-scale forest extraction for economic development to thrive. These strategies allow the state actors to work towards the existing economic development targets, but also to reinforce their hegemony over resources and resource users in more remote areas of the country. As a 
result, Laos is moving ahead with large-scale forest conversion schemes, while at the same time strengthening control over forest communities and their rights and uses of forest. However, I highlight that REDD+ is not the main, or only reason for state territorialization. Rather, it is one of the instruments used in support of Lao state territorial politics. The instrument has been added on to layers of previous colonial and post-colonial territorialization processes, largely continuing their logic, narratives and management practices.

Approaching REDD+ as a vehicle of state territorialization has a number of economic, social and political dimensions and implications. In economic terms, while lacking economic viability in terms of REDD+ payments in Laos (see also Cole 2017; Ingalls and Dwyer 2016) and being uncompetitive in comparison to large-scale land concessions and development industries, REDD+ has been reinvented to simply provide funding to run the forest bureaucracy and 'forestry as usual' practices. Operating in this way, the instrument advances and supports the Laos political economy, political elite and power establishment, all of which favor economic growth based on forest extraction and land investments, while communities' forest uses are challenged. Politically, REDD+ has likewise not challenged the mainstream political power in the country, which is led by the traditionally strongest actor - the central government (Creak and Barney forthcoming; Ramcilovic-Suominen et al. 2019; Stuart-Fox 2005, 2006). The DoF is the central organization and has the principal say concerning REDD+ implementation. The role of international development partners is similarly significant. Civil society engagement has remained poor (Ramcilovic-Suominen et al. 2019; RamcilovicSuominen and Nathan forthcoming), an issue which, due to limitations in length, is omitted from this article. REDD+ has also continued and to some extent provided a new impetus for directing ethnic minorities through targeting their modes of subsistence. The discourse around the 'undeveloped North needing modernization' (Baird and Shoemaker 2007; Lestrelin 2010; Singh 2012) is continued in REDD+, as evident in its focus on piloting activities in the northern part of the country largely populated by ethnic minorities. This brings the state and state rules, as well as Lao culture and notions of development and modernization, closer to these minorities. Finally, the societal implications of REDD+ are likely to be serious, especially in a long run. By addressing small-scale drivers, such as subsistence agriculture and small-scale forest uses, the REDD+ instrument directly limits villagers' main source of livelihoods, construction material and food - a finding which is in accordance with studies elsewhere (Mahanty et al. 2011; Tacconi et al. 2013).

Within REDD+, donors, development partners and domestic governments come together to address the problem of deforestation, contribute to carbon sequestration in a cost-efficient manner and benefit the poor (Angelsen 2008). However, the way in which REDD+ provinces are selected and the drivers of deforestation addressed to date, suggest that REDD+ is unlikely to achieve these stated goals in Laos. Rather, by targeting village forestry, and rural forest users and their practices, REDD+ is likely to further exclude the rural population from accessing forests and resources (see also Ramcilovic-Suominen and Nathan forthcoming). There is a need for further village level research and analysis of the effects of REDD+ project implementation on forest communities' access and rights to forest and land in Laos.

\section{References}

Alden Wily, L. 2012. Looking back to see forward: the legal niceties of land theft in land rushes. The Journal of Peasant Studies 39(3-4): 751-775.

Angelsen, A. (with M. Brockhaus, M. Kanninen, E. Sills, W.D. Sunderlin and S. Wertz-Kanounniko (eds.). 2009. Realising REDD+: national strategy and policy options. Bogor: CIFOR.

Angelsen, A. 2008. (ed.). Moving ahead with REDD issues, options and implications. Bogor: CIFOR.

Baird, I.G. 2010. The Hmong come to Southern Laos: local responses and the creation of racialized boundaries. Hmong Studies Journal 11: 1-38.

Baird, I.G. 2011. Turning land into capital, turning people into labour: primitive accumulation and the arrival of large-scale economic land concessions in the Lao People's Democratic Republic. New Proposals: Journal of Marxism and Interdisciplinary Inquiry 5(1): 10-26.

Baird, I.G. 2015. Translocal assemblages and the circulation of the concept of "indigenous peoples" in Laos. Political Geography 46: 54-64. 
Baird, I.G. and B. Shoemaker. 2007. Unsettling experiences: internal resettlement and international aid agencies in Laos. Development and Change 38: 865-888.

Barney, K. 2008. China and the production of forestlands in Laos: a political ecology of transnational enclosure. In J. Nevins and N.L. Peluso (eds.). Taking Southeast Asia to market: commodities, nature, and people in the neoliberal age. Cornell University Press. Pp. 91-107.

Barney, K. 2009. Laos and the making of a 'relational' resource frontier. The Geographical Journal 175: 146159.

Bassett, T.J. and D. Gautier. 2014. Regulation by territorialization: the political ecology of conservation \& development territories. EchoGéo 29.

Batterbury S.P.J. 2018. Political ecology. In Castree N., M. Hulme and J. Proctor (eds.). The companion to environmental studies. London: Routledge. Pp. 439-442.

Brockhaus, M. and M. Di Gregorio. 2014. National REDD+ policy networks: from cooperation to conflict. Ecology and Society 19(4): 14.

Broegaard, R.B., T. Vongvisouk and O. Mertz. 2017. Contradictory land use plans and policies in Laos: tenure security and the threat of exclusion. World Development 89: 170-189.

Bryant, R. 1998. Power, knowledge and political ecology in the third world: a review. Progress in Physical Geography 22(1): 79-94.

Bryant, R. (ed.). 2015. The international handbook of political ecology. Cheltenham: Edward Elgar.

Cole, R., G. Wong, M. Brockhaus, M. Moeliono and M. Kallio. 2017. Objectives, ownership and engagement in Lao PDR's REDD+ policy landscape. Geoforum 83: 91-100.

Corbera, E. and H. Schroeder. 2011. Governing and Implementing REDD+. Environmental Science \& Policy 14: 89-99.

Cramb R.A., C.J. Pierce Colfer, W. Dressler, P. Laungaramsri, Q.T. Le, E. Mulyoutami, N.L. Peluso and R.L. Wadley. 2009. Swidden transformations and rural livelihoods in Southeast Asia. Human Ecology 37(3): 323-346.

Creak, S. and K. Barney. Forthcoming. Party-state governance and rule in Laos. Journal of Contemporary Asia. Manuscript ID: RJOC-2017-0281.R1

DoF (Department of Forestry). 2010 Readiness Preparation Proposal (R-Pp) Lao PDR. Vientiane, Lao PDR: Forest Carbon Partnership Facility (FCPF) of the World Bank and Department of Forestry, Ministry of Agriculture and Forestry.

Dressler, W.H, D. Wilson, J. Clendenning, R. Cramb, R. Keenan, S. Mahanty, T.B. Bruun, O. Mertz and R.D. Lasco. 2016. The impact of swidden decline on livelihoods and ecosystem services in Southeast Asia: a review of the evidence from 1990 to 2015. Ambio 46: 291-310.

Dressler, W.H., S. Mahanty, J. Clendenning and P. To. 2015. Rearticulating governance through carbon in the Lao PDR? Environment and Planning C: Government and Policy. 33(5): 1265-1283.

Ducourtieux, O., J.R. Laffort and S. Sacklokham. 2005. Land policy and farming practices in Laos. Development and Change 36(3): 499-526.

Dwyer, M. 2007. Turning land into capital: a review of recent research on land concessions for investment in Lao PDR (Vol. 1 and 2). Unpublished Reports. Vientiane: Land Issues Working Group.

Dwyer, M. and M. Ingalls. 2015. REDD at the crossroads: choices and tradeoffs for 2015-2020 in Laos. Working Paper 17. Bogor: CIFOR.

Dwyer, M., M. Ingalls and I.G. Baird. 2016. The security exception: development and militarization in Laos's protected areas. Geoforum 69: 207-217.

Ece, M., J. Murombedzi and J. Ribot. 2018. Disempowering democracy: local representation in community and carbon forestry in Africa. Conservation and Society 15(4): 357-370.

ERPD (Emission Reductions Program Document). 2018. Forest Carbon Partnership Facility (FCPF) Carbon Fund Emission Reductions Program Document (ER-PD). Promoting REDD+ through governance, forest landscapes \& livelihoods in Northern Lao PDR. 26 March, 2018. 
Evans, G. 2002. A short history of Laos: the land in between. Sydney: Allen \& Unwin.

Evrard, O. and Y. Goudineau. 2004. Planned resettlement, unexpected migrations and cultural trauma in Laos. Development and Change 35(5): 937-962.

FCPF (Forest Carbon Partnership Facility). 2015. Carbon Fund ER-PIN (Emission Reductions Program Idea Note (ER-PIN). Lao PDR: Promoting REDD+ through Governance, Forest landscapes and Livelihoods in Northern Lao PDR.

Fletcher, R., W.H. Dressler, B. Büscher and Z.R. Anderson. 2016. Questioning REDD+ and the future of market-based conservation. Conservation Biology 30: 673-675.

Fox, J. 2002. Siam Mapped and mapping in Cambodia: boundaries, sovereignty, and indigenous conceptions of space. Society and Natural Resources 15(1): 65-78.

Fox, J., Y. Fujita, D. Ngidang, N.L. Peluso, L. Potter, N. Sakuntaladewi, J. Sturgeon and D. Thomas. 2009. Policies, political-economy, and swidden in Southeast Asia. Hum Ecology 37: 305-322.

Ingalls M.L. and M.B. Dwyer. 2016. Missing the forest for the trees? Navigating the trade-offs between mitigation and adaptation under REDD. Climatic Change 136(2): 353-366.

Katz, L. 2010. Red tape and gridlock. Canadian Journal of Law and Jurisprudence 23(1): 99-123.

Kelly, A.B. and N.L. Peluso. 2015. Frontiers of commodification: state lands and their formalization. Society and Natural Resources 28(5): 473-495.

Kenney-Lazar, M. 2011. Dispossession, semi-proletarianization, and enclosure: primitive accumulation and the land grab in Laos. Paper presented at the International conference on Global Land Grabbing, 6-8April 2011. Available at: https:/www.future-agricultures.org/wp-content/uploads/pdfarchive/Miles\%20Kenney-Lazar.pdf (Accessed July 2019)

Kenney-Lazar, M. 2013. Shifting cultivation in Laos: Transitions in policy and perspective. Report. Sector Working Group-Agriculture and Rural Development (SWG-ARD).

Kenney-Lazar, M. 2017. Governing dispossession: relational land grabbing in Laos. Annals of the American Association of Geographers 108(3): 679-694.

Kingsbury, D. 2017. Politics in contemporary Southeast Asia. London: Routledge.

Koch, S. 2017. The struggle over Lao PDR's forests: new opportunities for improved forest governance? Pacific Geographies 47(January/February): 4-13.

Lavers, T. 2012. 'Land grab' as development strategy? The political economy of agricultural investment in Ethiopia. The Journal of Peasant Studies 39(1): 105-132.

Lavers, T. and F. Boamah. 2016. The impact of agricultural investments on state capacity: a comparative analysis of Ethiopia and Ghana. Geoforum 72: 94-103.

Lestrelin, G. 2009. Changing lives, changing nature(s): socio-environmental transitions in the uplands of the Lao PDR, PhD dissertation. Durham University.

Lestrelin, G. 2010. Land degradation in the Lao PDR: discourses and policy. Land Use Policy 27(2): 424-439.

Lestrelin, G., J-C. Castella and J. Bourgoin. 2012. Territorialising sustainable development: the politics of landuse planning in Laos. Journal of Contemporary Asia 42(4): 581-602.

Lund, C. 2011. Fragmented sovereignty: land reform and dispossession in Laos. Journal of Peasant Studies 38(4): 885-905.

Lund, C. and N.F. Rachman. 2018. Indirect recognition: frontiers and territorialization around Mount HalimunSalak National Park, Indonesia. World Development 101: 417-428.

Lund, J.F., E. Sungusia, M.B. Mabele and A. Scheba. 2017. Promising change, delivering continuity: REDD as conservation fad. World Development 89: 124-139.

MAF (Ministry of Agriculture and Forestry) 2018. FCPF Emission Reductions Program Document (ER-PD) of Lao PDR. Promoting REDD+ through Governance, Forest Landscapes and Livelihoods in Northern Lao PDR. Forest Carbon Partnership Facility. (Accessed February 2019) 
Mahanty, S., A. Bradley and S. Milne. 2015. The forest carbon commodity chain in Cambodia's voluntary carbon market. In Milne, S. and S. Mahanty (eds.). Conservation and development in Cambodia: exploring frontiers of change in nature, state and society. New York: Routledge. Pp. 177-200.

Mahanty, S., W.H. Dressler, S. Milne and C. Filer. 2013. Unravelling property relations around forest carbon. Singapore Journal of Tropical Geography 34: 188-205.

McElwee, P.D. 2016. Doing REDD+ work in Vietnam: will the new carbon focus bring equity to forest management? In Fiske, S. and S. Paladino (eds.). The carbon fix: global equity and the new environmental regime. Berkeley: Left Coast Press. Pp. 184-200.

McElwee, P.D., Nguyen Hai Van, Nguyen Viet Dung, Tran Huu Nghi, Le Thi Van Hue, Nghiem Phuong Tuyen and Vu Dieu Huong. 2016. Using REDD+ policy to facilitate climate adaptation at the local level: synergies and challenges in Vietnam. Forests 8: 1.

Moore, P., M. Pholsena, K. Phommachanh and R. Glémet. 2013. Review of statutory and customary law in the Xe Champhone Ramsar Site, Lao PDR: implications for a rights-based approach to conservation. Vientiane: IUCN.

Mustalahti, I. and D.T. Tassa. 2012. Analysis of three crucial elements of REDD+ in participatory forest management. Scandinavian Journal of Forestry Research 27(2): 200-209.

Mustalahti, I., M. Cramm, S. Ramcilovic-Suominen and Y.T. Tegegne. 2017. Resources and rules of the game: participation of civil society in REDD+ and FLEGT-VPA processes in Lao PDR. Forests 8, 50.

Myers, R., A.M. Larson, A. Ravikumar, L.F. Kowler, A. Yang and T. Trench. 2018. Messiness of forest governance: how technical approaches suppress politics in REDD+ and conservation projects. Global Environmental Change 50: 214-324.

Pasgaard, M. and O. Mertz. 2016. Desirable qualities of REDD+ projects not considered in decisions of project locations. Environmental Research Letters 11: 114014.

Peluso, N.L. and P. Vandergeest. 2001. Genealogies of the political forest and customary rights in Indonesia, Malaysia and Thailand. The Journal of Asian Studies 60(3):761-812.

Peluso, N.L. and P. Vandergeest. 2011. Political ecologies of war and forests: counterinsurgencies and the making of national natures. Annals of the Association of American Geographers 101(3): 587-608.

Peluso, N.L. 2005. Seeing property in land use: local territorializations in West Kalimantan, Indonesia. Geografisk Tidsskrift, Danish Journal of Geography 105(1): 1-15.

Phelps, J., E.L. Webb and A. Agrawal. 2010. Does REDD threaten to recentralize forest governance? Science 328(5976): 312-313.

Phraxayavong, W. 2009. History of aid to Laos: motivations and impacts. Thailand: Silkworm Books.

PRAP (Provincial REDD+ Action Plan) 2017. PARP for Houaphan Province, LAO PDR. Draft 2 Feb. 2017.

Ramcilovic-Suominen, S. and I. Nathan, I. forthcoming. REDD+ in policy translation: discourses and storylines from global to village level in Laos. Journal of Political Ecology.

Ramcilovic-Suominen, S., M. Lovric and I. Mustalahti. 2019. Mapping policy actor networks and their interests in the FLEGT Voluntary Partnership Agreement in Lao PDR. World Development 118: 128-148.

Rasmussen, M.B. and C. Lund. 2018. Reconfiguring frontier spaces: territorialization and resource control. World Development 101: 388-399.

Robbins, P. 2004. Political ecology: a critical introduction. Oxford: Blackwell.

Sack, R.D. 1986. Human territoriality: its theory and history. Cambridge: Cambridge University Press.

Scott, J.C. 1998. Seeing like a state: how certain schemes to improve the human condition have failed. New Haven: Yale University Press.

Singh, S. 2012. Natural potency and political power: forests and state authority in contemporary Laos. Honolulu: University of Hawaii Press.

Smith, H., K. Barney, N. Byron, S. Van Der Meer, S. Phimmavong, R. Keenan and V. Vongkhamsao. 2016. Tree plantations in Lao PDR: policy framework and review. Project report. Canberra: ACIAR. 
Stern, H.N. and G. Britain. 2007. The economics of climate change: the Stern Review. Cambridge: Cambridge University Press.

Stuart-Fox, M. 1997. A history of Laos. Cambridge: Cambridge University Press.

Stuart-Fox, M. 2005. Politics and reform in Lao People's Democratic Republic. Working Paper 126. Perth: Asia Research Centre, Murdoch University.

Stuart-Fox, M. 2006. The political culture of corruption in the Lao PDR. Asian Studies Review 30(1): 59-75.

Stuart-Fox, M. 1983. Marxism and Theravada Buddhism: the legitimation of political authority in Laos. Pacific Affairs 56: 428-454.

Suhardiman, D. and M. Giordano. 2014. Legal plurality: an analysis of power interplay in Mekong hydropower. Annals of the Association of American Geographers 104(5): 973-988.

Suhardiman, D., O. Keovilignavong and M. Kenney-Lazar. 2019. The territorial politics of land use planning in Laos. Land Use Policy 83: 346-356.

Tacconi, L., S. Mahanty and H. Suich. 2013. The livelihood impacts of Payments for Environmental Services and Implications for REDD+. Society and Natural Resources 26(6): 733-744.

Thomas, I., N. Chorn, D. Braeutigam, S. Thongmanivong, S. Boulidam, T. Phimminit, K. Hurni and C. Hett. 2010. Analysis of land use and forest changes and related driving forces in the Lao PDR. A contribution to the REDD+ Readiness Plan. Department of Forestry.

Thompson, M.C., M. Baruah and E.R. Carr. 2011. Seeing REDD+ as a project of environmental governance. Environmental Science \& Policy 14: 100-110.

To, P.X. 2015. State territorialization and illegal logging: the dynamic relationships between practices and images of the state in Vietnam. Critical Asian Studies 47(2): 229-252.

To, P.X., N.B. Treanor and K. Canby. 2017. Impacts of the Laos log and sawnwood export bans: significant reductions in the exports to major markets of Vietnam and China in 2016. Washington DC: Forest Trends.

UNDP (United Nations Development Program). 2011a. People's perspective on access to justice survey in four provinces of Lao PDR. UNDP-Laos.

UNDP (United Nations Development Program). 2011b. Customary law and practice in Lao PDR. New York: UNDP.

Vandergeest, P. 1996. Mapping nature: territorialization of forest rights in Thailand. Society and Natural Resources 9: 159-175.

Vandergeest, P. and A. Unno. 2012. A new extraterritoriality? Aquaculture certification, sovereignty, and empire. Political Geography. 31(6): 358-367.

Vandergeest, P. and N.L. Peluso. 1995. Territorialization and state power in Thailand. Theory and Society 24: 385-426.

Vandergeest, P. and N.L. Peluso. 2006. Empires of forestry: professional forestry and state power in Southeast Asia, Part 1. Environment and History 12: 31-64.

Vongvisouk, T., G. Lestrelin, J-C. Castella, O. Mertz, R.B. Broegaard and S. Thongmanivong. 2016. REDD+ on hold: lessons from an emerging institutional setup in Laos. Asia Pacific Viewpoint 57(3): 393-405. 